\title{
Therapeutic Efficacy of Erythropoietin Alpha and Erythropoietin Beta in Anemia of Chronic Kidney Disease
}

\author{
Sommiya Dashti, Murtaza Dhrolia, Ruqaya Qureshi, Kiran Nasir and Aasim Ahmad \\ Department of Nephrology, The Kidney Centre Postgraduate Training Institute, Karachi, Pakistan
}

\begin{abstract}
:
Objective: To compare the effectiveness of erythropoietin alpha and erythropoietin beta in anemia management in the hemodialysis population.

Study Design: Quasi-experimental study.

Place and Duration of Study: Department of Nephrology, The Kidney Center Postgraduate Training Institute (TKC-PGTI), Karachi, from December 2019 to July 2020.

Methodology: All participants were initially started on erythropoietin alpha and then converted to erythropoietin beta after three months. The effectiveness of the erythropoietin alpha and erythropoietin beta was calculated on the basis of net change of mean hemoglobin and mean hematocrit level in the last four weeks on either erythropoietin therapy.

Results: A total of 80 patients completed the study, in which 47 (58.8\%) were males while $33(41.3 \%)$ were females. The mean age was $59.7 \pm 14.7$ years. The net mean hemoglobin change during last 04 weeks was $-0.19 \pm 1.2$ and $-0.03 \pm 1.0$ for erythropoietin alpha and erythropoietin erythropoietin beta, respectively $(p=0.41)$. The net mean hematocrit change during the last four weeks was- $0.45 \pm 3.9$ and $-0.49 \pm 3.7$ for erythropoietin alpha and erythropoietin beta, respectively ( $p$ $=0.95$ ). The mean weekly erythropoietin dosage per $\mathrm{Kg}$ body weight during the last four weeks was $177.6 \pm 130.4$ $\mathrm{IU} / \mathrm{Kg} /$ week for erythropoietin alpha and $121.3 \pm 69.6 \mathrm{IU} / \mathrm{Kg} /$ week for erythropoietin beta $(p=<0.001)$.

Conclusion: Erythropoietin alpha and erythropoietin beta have similar therapeutic efficacy in anemia management in chronic kidney disease patients. Reduced dosage of erythropoietin beta achieves and maintains the target hemoglobin level.
\end{abstract}

Key Words: Efficacy, Erythropoietin, Anemia, Chronic kidney disease.

How to cite this article: Dashti S, Dhrolia M, Qureshi R, Nasir K, Ahmad A. Therapeutic Efficacy of Erythropoietin Alpha and Erythropoietin Beta in Anemia of Chronic Kidney Disease. J Coll Physicians Surg Pak 2021; 31(12):1417-1421.

\section{INTRODUCTION}

Anemia is the prevalent complication of chronic kidney disease (CKD), especially Stage $V,{ }^{1}$ and is associated with an increased risk of death and hospitalisation. ${ }^{2}$ Anemia in CKD is typically normocytic, normochromic, and hypo-proliferative. It is multifactorial, with iron depletion; and erythropoietin deficiency being the two most common causes. ${ }^{3}$ The availability of recombinant human erythropoietin (rHuEPO) since the early 1980s has dramatically changed the management of anemia in patients with CKD. ${ }^{4,5}$ However, the use of erythropoiesis-stimulating agents (ESAs) presents a significant cost burden in the management of anemia of chronic kidney disease (CKD), especially in resource limited health set-up.

Correspondence to: Dr. Sommiya Dashti, Department of Nephrology, The Kidney Centre Postgraduate Training Institute, Karachi, Pakistan

E-mail: sommiyadashti@gmail.com

Received: May 21, 2021; Revised: September 11, 2021;

Accepted: October 29, 2021

DOI: https://doi.org/10.29271/jcpsp.2021.12.1417
The first rHuEPO produced was erythropoietin alpha, followed by other agents as erythropoietin beta, methoxy polyethylene glycol-epoetin beta, delta, darbepoetin-alpha, omega, and several related products. ${ }^{6}$ Among severaltypes of ESAs, erythropoietin alpha and erythropoietin beta are two short-acting ESAs that are frequently used in the management of anemia of CKD. In some studies, both agents have shown the same efficacy in treating CKD-induced anemia. ${ }^{7.8}$ The Kidney Disease Improving Global Outcomes (KDIGO) guidelines also suggest that erythropoietin alpha and erythropoietin beta have the same efficacy and require the same dose to be administered to patients with CKD-induced anemia. ${ }^{9}$

Differences in the carbohydrate moieties of the rHuEPOs determine differences in the pharmacokinetic and pharmacodynamics properties between these agents. The terminal elimination half-life after intravenous administration of erythropoietin beta was $20 \%$ longer than that of erythropoietin alpha. After subcutaneous administration, there was delayed drug absorption with erythropoietin beta compared with erythropoietin alpha. ${ }^{10}$ The prolonged half-lifefollowing subcutaneousadministration of erythropoietin beta supports the use of subcutaneous erythropoietin beta, administered once weekly, at least in the maintenance phase of renal anemia treatment both, due to its 
pharmacological as well as economic considerations. ${ }^{11-13}$ Some studies have also shown that a reduced dose of erythropoietin beta was needed to maintain targethemoglobin $(\mathrm{Hb})$ concentration. ${ }^{14}$

Pakistan is a resource-limited country, where less than $10 \%$ of End Stage Renal Disease (ESRD) patients receive renal replacement therapy (RRT), and up to $70 \%$ of those starting dialysis stop treatment due to cost within the first three months. ${ }^{15}$ Erythropoietin alpha was initially the only ESA used for anemia management in hemodialysis (HD) in Pakistan (and especially in the dialysis centre) due to the availability of its less costly brand, however, expansion of market and pharmaceutical industries' competition recently allowed availability of erythropoietin beta with a comparable price to that of erythropoietin alpha. Although, widely believed that the dosage requirements of erythropoietin alpha and erythropoietin beta are the same, the proven efficacy and safety profile of erythropoietin beta, combined with the increased convenience of less frequent dosing, and reduce dose requirement is an additional benefit. This developed the authors' interest to study the effectiveness of erythropoietin alpha and erythropoietin beta in HD population because any ESA that can decrease dose requirement and financial burden on HD patient, will be of great benefit and can help more patients to reach their therapeutic targets in the management of renal anemia especially in resource limited country alike Pakistan.

The objective of this study was to compare the effectiveness of erythropoietin alpha and erythropoietin beta in anemia management in the hemodialysis population.

\section{METHODOLOGY}

This prospective quasi-experimental study was conducted in the Department of Nephrology, The Kidney Centre Postgraduate Training Institute (TKC-PGTI) after approval by the Institutional Ethical Review Committee. TKC-PGTI follows the standards defined by European best practice guidelines, and longterm maintenance HD patients dialysed for four hours three times a week.

A total of 90 patients of both genders, aged above 18 years, undergoing maintenance $\mathrm{HD}$ for $>3$ months, with stable $\mathrm{Hb}$ for 3 months (defined as change in $\mathrm{Hb}$, not more than or less than 2 $\mathrm{gm} / \mathrm{dl}$ from mean $\mathrm{Hb}$ in 3 months), having adequate iron stores (defined as transferrin saturation (TSAT) $\geq 20 \%$ ), complying with dialysis therapy and medications as advised by treating nephrologist, were enrolled in the study through non-probability consecutive sampling. Written informed consents were taken. Patients could withdraw from the study at any time and for any reason. In addition, patients could be withdrawn at the investigator's discretion in the event of inter-current illness, adverse events, or protocol violation. Patients with anemia secondary to other causes apart from CKD; decompensated liver failure, history of or active blood coagulation disorders, history of malignancy within the last five years, any red blood cell transfusion during the last three months, an event of active bleeding in 30 days before the study, major surgery within three months before study, any history of hospital admission requiring blood transfusion in the duration of the study, non-adherence to medications and women if they became pregnant, were excluded to avoid their misleading influence on the result. Exclusion criteria also included patients who were non-compliant to dialysis therapy or not receiving prescribed dialysis doses.

$\mathrm{Hb}$ level at the start of the study was taken as a baseline. Target $\mathrm{Hb}$ was $10-12 \mathrm{mg} / \mathrm{dl}$ according to KDIGO guidelines. ${ }^{16}$ Only subcutaneous injections were used for both erythropoietin alpha and erythropoietin beta. All injections were administered by experienced personnel at this dialysis centre. All participants were initially started on erythropoietin alpha as the dose as the discretion of treating nephrologist or those who were already on erythropoietin alpha, continued to receive same dose. After three months, all participants were converted to erythropoietin beta as the dose $25 \%$ less than that of erythropoietin alpha, based on pharmacokinetic difference and studies that suggest reduced dose requirement of erythropoietin beta to maintain target $\mathrm{Hb}$ concentration compared to erythropoietin alpha. ${ }^{10,14}$ $\mathrm{Hb}$ at three month of study (that of on erythropoietin alpha), was considered as baseline $\mathrm{Hb}$ for erythropoietin beta. Dose was adjusted for both ESA during study period, only once a month, based on the patient response to maintained the $\mathrm{Hb}$ level in the target range. If the hemoglobin level increased $>12 \mathrm{~g} / \mathrm{dl}$, the dose was reduced by approximately $25 \%$ (75\%) of the previous dose) or vice versa, if $\mathrm{Hb}$ level decreases $<10 \mathrm{~g} / \mathrm{dl}$. If the hemoglobin continues to increase, the dose was temporarily withheld until the hemoglobin begins to decrease; at that point, therapy was re-initiated at a dose approximately $25 \%$ below the previous dose. Patients were evaluated every four weeks for the study period. The first two weeks after starting both ESA were considered the washout period, and the next six weeks are considered for dose adjustment so that the steady effect of both ESA therapies can be assessed appropriately. TSAT was maintained $>20 \%$ throughout the study period by adjustment of iron replacement. The clinical, demographic, and personal information of each participating patient was recorded in a proforma.

The difference in mean $\mathrm{Hb}$, mean hematocrit $(\mathrm{Hct})$ and mean weekly erythropoietin dosage per $\mathrm{Kg}$ of body weight was calculated for the last four weeks of both ESA therapies. The effectiveness of the erythropoietin alpha and erythropoietin beta was calculated based on of net change of mean $\mathrm{Hb}$ and mean $\mathrm{Hct}$ level at three months from their respective mean $\mathrm{Hb}$ and mean Hct level at two months in respect to the mean dosage of erythropoietin used per $\mathrm{Kg}$ of body weight per week during the same time period. Proportion of patients with any $\mathrm{Hb}$ measurement outside the target range (10-12) during the study period were also compared with $\mathrm{Hb}$ level above $13 \mathrm{~g} / \mathrm{dl}$ was considered as safety outcome.

Data was entered and analysed by IBM version 21 of SPSS. Cleaning and coding of data was done before analysis. Mean values with standard deviation were calculated for continuous 
normally distributed variables; while for skewed data, median with interquartile were also observed along with mean \pm STD. For categorical variables, frequencies with percentages were obtained. Paired sample t-test was used to observe any mean difference in $\mathrm{Hb}$, Hct and ESA dosage of patient in case of normally distributed data, on the other hand in case of skewed distribution; Wilcoxon sign rank test was applied to observe any differences in above mentioned parameters. Normality of data was assessed by Shapiro-Wilk test. P-value of less than or equal to 0.05 was considered significant.

\section{RESULTS}

A total of 90 participants were enrolled in the study. Two participants expired during the study period, secondary to cause unrelated to ESA complication, six participants declined the consent in middle of the study and withdrew, while two participants were lost to follow-up because of change of dialysis centre. A total of 80 patients completed the study, in which 47 (58.8\%) were males, while 33 (41.3\%) were females. The mean age was 59.7 \pm 14.7 years. The majority of patients had CKD of unknown etiology $46(57.5 \%)$, while the most prevalent comorbid was HTN 74 (92.5\%). Table I demonstrates the baseline characteristics of the study participants.

Table l: Baseline (week 0 ) characteristics of study participants $(n=80$ ).

\begin{tabular}{|l|l|}
\hline Variables & $\begin{array}{l}\text { Mean (SD) \& median, } \\
\text { IQR or } \mathbf{n}(\%)\end{array}$ \\
\hline Age & $59.7 \pm 14.7 \& 61.5,18$ \\
\hline Gender & $47(58.8)$ \\
\hline Male & $33(41.3)$ \\
\hline Female & $5.7 \pm 5.4 \& 4,4$ \\
\hline Dialysis Vintage & $46(57.5)$ \\
\hline Cause of CKD & $16(20)$ \\
\hline Unknown & $12(15)$ \\
\hline Glomerulonephritis & $4(5)$ \\
\hline Diabetes & $2(2.5)$ \\
\hline Stone disease & $74(92.5)$ \\
\hline ADPKD & $24(30)$ \\
\hline Comorbidities & $17(21.3)$ \\
\hline Hypertension & $63.5 \pm 15.1 \& 64,18$ \\
\hline Diabetes & $290 \pm 287.5 \& 175,352$ \\
\hline Ischemic heart disease & $5.5 \pm 2.8 \& 5,1$ \\
\hline Weight & $560 \pm 550.4 \& 457,363.5$ \\
\hline iPTH & $46 \pm 66.4 \& 32,21.2$ \\
\hline C-reactive protein & $10.9 \pm 1.2 \& 11,1.3$ \\
\hline Ferritin & $34.4 \pm 4 \& 34.9,5.5$ \\
\hline Transferrin saturation & $=$ Adult dominant polycystic kidney \\
\hline Hemoglobin & \\
\hline Hematocrit & $\begin{array}{l}|l| \\
\text { CKD = Chronic kidney disease, ADPKD } \\
\text { disease, iPTH = Intact parathyroid hormone. }\end{array}$ \\
\hline
\end{tabular}

The effectiveness of the erythropoietin alpha and erythropoietin beta was calculated based on the net change of mean hemoglobin and mean hematocrit level in the last four weeks on either erythropoietin therapy.

Net mean $\mathrm{Hb}$ change during the last four weeks was $0.19 \pm 1.2$ and $-0.03 \pm 1.0$ for erythropoietin alpha and erythropoietin beta, respectively; which was statistically insignificant $(p=$ 0.163 and 0.315 , respectively). The net mean hematocrit change during last four weeks was $-0.45 \pm 3.9$ and $-0.49 \pm 3.7$ for erythropoietin alpha and erythropoietin beta, respectively; which was again statistically not significant $(p=0.338$ and 0.12 , respectively, Tablell).

Table ll: Change in hemoglobin and hematocrit in last four week.

\begin{tabular}{|l|c|c|}
\hline & $\begin{array}{c}\text { Erythropeoietin aplha } \\
\text { Mean } \pm \text { STD }\end{array}$ & $\begin{array}{c}\text { Erythropoiethin beta } \\
\text { Mean + STD }\end{array}$ \\
\hline Hemoglobin & $10.9 \pm 0.86$ & $10.4 \pm 0.94$ \\
\hline At Month 03 & $11.1 \pm 1$ & $10.4 \pm 1$ \\
\hline At Month 02 & $-0.19 \pm 1.2$ & $-0.03 \pm 1.0$ \\
\hline $\begin{array}{l}\text { Change in last 4 } \\
\text { weeks }\end{array}$ & 0.163 & 0.315 \\
\hline p-value & $34.8 \pm 3 \& 34.9,3$ & $32.5 \pm 3.5 \& 33,4.2$ \\
\hline Hematocrit & $35.2 \pm 3.5 \& 35.6,5.5$ & $33 \pm 3.3 \& 33.2,5.4$ \\
\hline At Month 03 & $-0.03 \pm 1$ & $-0.5 \pm 3.7$ \\
\hline At Month 02 & 0.338 & 0.120 \\
\hline $\begin{array}{l}\text { Change in last 4 } \\
\text { weeks }\end{array}$ &
\end{tabular}

The mean weekly erythropoietin dosage per $\mathrm{Kg}$ body weight during the last four weeks was $177.6 \pm 130.4 \mathrm{IU} / \mathrm{kg} / \mathrm{week}$ for erythropoietin alpha and $121.3 \pm 69.6 \mathrm{IU} / \mathrm{kg} /$ week for erythropoietin beta. Dosage of erythropoietin alpha and erythropoietin beta had a statistically significant difference for maintaining $\mathrm{Hb}$ level between 10 and $12 \mathrm{mg} / \mathrm{dl} \quad(p<0.001)$. The authors observed that $29.3 \%$ less dosage of erythropoietin beta was required to achieve targeted $\mathrm{Hb}$ in CKD patients as compare to erythropoietin alpha (Table III).

Table III: Comparison of dosage of erythropoietin alpha and erythropoietin beta.

\begin{tabular}{|c|c|c|c|}
\hline Doses & $\begin{array}{c}\text { Erythropoietin } \\
\text { alpha } \\
\text { Mean } \pm \text { STD \& } \\
\text { Median, IQR }\end{array}$ & $\begin{array}{c}\text { Erythropoietin } \\
\text { beta } \\
\text { Mean } \pm \text { STD \& } \\
\text { Median, IQR } \\
\end{array}$ & p-value \\
\hline $\begin{array}{l}\text { Total dose of last } 04 \\
\text { weeks }\end{array}$ & $\begin{array}{c}43343 \pm 33716 \& \\
40000,20000\end{array}$ & $\begin{array}{c}29134 \pm 15553 \\
\& \\
30000,25000\end{array}$ & $<0.001$ \\
\hline Dosage per week & $\begin{array}{c}9524 \pm 6040 \& \\
8308,7692\end{array}$ & $\begin{array}{c}5724 \pm 2692 \& \\
5000,7077\end{array}$ & $<0.001$ \\
\hline Dosage per Kg per week & $\begin{array}{c}177.6 \pm 130 \& \\
1355,145\end{array}$ & $\begin{array}{c}121 \pm 69.6 \& \\
84,68.5\end{array}$ & $<0.001$ \\
\hline
\end{tabular}

The proportion of patients with any $\mathrm{Hb}$ measurement outside the target range (10-12) during the study period was also compared. $\mathrm{Hb}$ of 15 patients during erythropoietin alpha and 25 patients during erythropoietin beta therapy fell outside the range of $10-12 \mathrm{~g} / \mathrm{dl}$.

Although, this was statistically insignificant $(p=0.176)$, patient during erythropoietin alpha achieved $\mathrm{Hb}>12$ more than that of erythropoietin beta. One patient during erythropoietin alpha experienced $\mathrm{Hb}$ level above $13 \mathrm{~g} / \mathrm{dl}$, while none of the patients during erythropoietin beta experienced $\mathrm{Hb}$ level above $13 \mathrm{~g} / \mathrm{dl}$.

\section{DISCUSSION}

This prospective quasi-experimental study was conducted to study the effectiveness of erythropoietin alpha and erythropoietin beta in patients on hemodialysis. The potential confounding factors that can affect the response of ESA therapy on hemoglobin in hemodialysis patients, such as transferrin 
saturation and ferritin, iPTH, inflammatory markers as C-reactive protein, ${ }^{17}$ were also considered and were checked at the beginning of the study (Table I). The results of this study suggested that erythropoietin beta is similar to erythropoietin alpha in terms of their efficacy, while the mean weekly dosage per $\mathrm{Kg}$ requirement to maintain the $\mathrm{Hb}$ level within $10-12 \mathrm{~g} / \mathrm{dl}$ was significantly less for erythropoietin beta as compare to erythropoietin alpha.

The mean change in $\mathrm{Hb}$ level during the last four weeks was comparable for erythropoietin beta and erythropoietin alpha. Similar finding was found in two different randomised controlled trials from Iran, ${ }^{7,18}$ a study from Bosnia and Herzegovina, ${ }^{8}$ and a briefreportfrom UK. ${ }^{14}$

This is similar to the KDIGO guidelines, which suggest that erythropoietin alpha and erythropoietin beta have the same efficacy. ${ }^{9}$ One study from Indonesia found better achievement in mean $\mathrm{Hb}$ level with erythropoietin alpha as compared to erythropoietin beta; ${ }^{19}$ however, they had a very small sample size and have not taken into account the potential effect of confounding factors between the groups. They have attributed the result of their study were probably confounded by iron status, malnutrition, inadequate hemodialysis, inflammation, and usage of angiotension receptor blocker drugs. The mean change in Hct level during the last four weeks was also found comparable between erythropoietin beta and erythropoietin alpha. This corresponds with the result from a study by Loughman etal. from UK and Prasetya et al. from Indonesia. ${ }^{19}$

The mean weekly erythropoietin dosage per $\mathrm{Kg}$ body weight of patients during the last four weeks of treatment necessary to maintain the $\mathrm{Hb}$ level within $10-12 \mathrm{~g} / \mathrm{dL}$ was $29.3 \%$ less for erythropoietin beta as compared to erythropoietin alpha. The present result corresponds with the study by Loughnan et al.., ${ }^{14}$ which also found that higher doses of erythropoietin alpha are required to maintain $\mathrm{Hb}$ in the target level than erythropoietin beta; however, only intravenous (IV) route was analysed in their study. Azmandian et al. analysed both IV and Sc route and found that the mean dose of erythropoietin during the whole study was higher in the erythropoietin alpha group (mean 20.87 $\mathrm{IU} / \mathrm{Kg} /$ week more than erythropoietin beta), but the difference was not statistically significant $(p=0.1){ }^{7}$ The result of the current study contradicts the KDIGO guidelines, which suggest that erythropoietin alpha or erythropoietin beta usually starts at the same dose. ${ }^{9}$ Ostrvica et al. evaluated the efficacy of epoetin alfa and beta (both IV and Sc) for correction of anemia in ESRD patients and found that patients needed approximately equal doses of erythropoietin alpha and erythropoietin beta to achieve and maintain the target level of $\mathrm{Hb}$ and hematocrit. ${ }^{8}$ This study had a small sample size.

In the current trial, the proportion of patients with any $\mathrm{Hb}$ measurement outside the target range in erythropoietin beta was higher than erythropoietin al pha. Although, this was statistically insignificant, patients during erythropoietin al pha achieved $\mathrm{Hb}>12$ more than that of erythropoietin beta. This might correlate with Prasetya et al. study which conclude that erythropoietin alpha gave better achievement of increasing hemoglobin parameter than erythropoietin beta; ${ }^{19}$ however, considering ability to maintain $\mathrm{Hb}$ within target range, both ESA were found similar. In the study by Azmandian et al., the proportion of patients with any $\mathrm{Hb}$ measurement outside the target range in erythropoietin alpha was higher than erythropoietin beta; and they proposed that a higher proportion of patients with maintenance success in the erythropoietin beta group suggests that erythropoietin beta is more successful than erythropoietin alpha in keeping patients in the target range of $\mathrm{Hb}$ level (10-12 $\mathrm{g} / \mathrm{dL})$.

Although, the current study was not designed to evaluate the safety between two ESA therapies, the authors found that only one patient on erythropoietin alpha achieved an $\mathrm{Hb}$ level above $13 \mathrm{~g} / \mathrm{dl}$, while none on erythropoietin beta. Astudy by Azmandian et al. found that erythropoietin beta and erythropoietin alpha havecomparable safety profile. ${ }^{7}$

In the current study, the cost of therapy between erythropoietin alpha and erythropoietin beta was not compared, which depends on the brand and their marketed price. However, as mentioned earlier, the expansion of market and pharmaceutical industries' competition recently allows availability of erythropoietin beta in a comparable price to that of erythropoietin alpha. Therefore, less dosage requirement for erythropoietin beta will reduce the financial burden on the hemodialysis patient, and can help more patients reach their therapeutic targets in the management of renal anemia especially in a resource-limited country like Pakistan.

So far, few studies have compared the dosage of erythropoietin alpha with erythropoietin beta. Some analysed only IV route, ${ }^{14,18}$ and its effect on $\mathrm{Hct},{ }^{14}$ while some had a small sample size. ${ }^{19}$ The authors analysed the effect of both $\mathrm{Hb}$ and Hct for ESA dosage, while quasi-experimental design of this study enabled the authors to exclude even subtle selection biases that can occur even in a well design RCTs, and to analyse a large number of patients on either ESA therapy so far to the best of authors' knowledge. Although a single-centre experience, small sample size and not assessing safety between both ESA are the major limitation of this study. This study can serve as a reference for the future researchers in designing and carrying out large, multicentre randomised controlled trials for efficacy and safety assessment between these two ESA therapies.

\section{CONCLUSION}

Both erythropoietin alpha and erythropoietin beta have similar therapeutic efficacy in anemia management in chronic kidney disease patients. A lower dosage of erythropoietin beta is required as compared to erythropoietin alpha to achieve and maintain target hemoglobin level.

\section{ETHICALAPPROVAL:}

This prospective quasi-experimental study was conducted after approval by the Ethical Review Committee of The Kidney Centre Postgraduate Training Institute (TKC-PGTI).

\section{PATIENTS' CONSENT:}

A written informed consent was taken from all patients. 


\section{CONFLICT OF INTEREST:}

The authors declared no conflict of interest.

\section{AUTHORS' CONTRIBUTION:}

SD: Literature search, study design and concept, questionnaire design, data collection.

MFD: Literature search, study design and concept, data analysis, data interpretation, drafting, revising it critically for important intellectual content.

$\mathrm{RQ}, \mathrm{KN}$ : Revising it critically for important intellectual content. AA: Data analysis, data interpretation, drafting, revising it critically for important intellectual content.

All authors approved the manuscript for the publication.

\section{REFERENCES}

1. McClellan W, Aronoff SL, Bolton WK, Hood S, Lorber DL, Tang $\mathrm{KL}$, et al. The prevalence of anemia in patients with chronic kidney disease. Curr Med Res Opin 2004; 20(9): 1501-10.

2. Ma JZ, Ebben J, Xia H, Collins AJ. Hematocrit level and associated mortality in hemodialysis patients. J Am SocNephrol 1999; 10(3):610-9. doi: 10.1681/ASN.V103610.

3. Babitt JL, Lin HY. Mechanisms of anemia in CKD. J Am SocNephrol 2012; 23(10):1631-4. doi: 10.1681/ASN. 2011111078.

4. Eschbach JW, Egrie JC, Downing MR, Browne JK, Adamson JW. Correction of the anemia of end-stage renal disease with recombinant human erythropoietin. New Eng J Med 1987; 316(2):73-8. doi: 10.1056/NEJM198707233170416.

5. Winearls C, Pippard M, Downing M, Oliver D, Reid C, Cotes PM. Effect of human erythropoietin derived from recombinant DNA on the anaemia of patients maintained by chronic haemodialysis. Lancet 1986; 328(8517):1175-8. doi: 10.1016/s0140-6736(86)92192-6.

6. Kalantar-Zadeh K. History of erythropoiesis-stimulating agents, the development of biosimilars, and the future of anemia treatment in nephrology. Am J Nephrol 2017; 45(3): 235-47. doi: 10.1159/000455387.

7. Azmandian J, Abbasi MR, Pourfarziani V, Nasiri AA, Ossareh $\mathrm{S}$, Jahromi SE, et al. Comparing therapeutic efficacy and safety of epoetin beta and epoetinalfa in the treatment of anemia in end-stage renal disease hemodialysis patients. Am J Nephrol 2018; 48(4):251-9. doi: 10.1159/000493097.

8. Ostrvica E, Mesic E, Ostrvica D, Delic J, Delic-Custendil S, Hukic F. Effectiveness of treating the renal anemia in chronic hemodialysed patients by epoietin alpha and beta. Med Res Arch 2010; 64(1):4.
9. Kidney disease: Improving global outcomes (KDIGO) anemia work group. KDIGO clinical practice guideline for anemia in chronic kidney disease. Kidney Int Suppl 2012; 2(4):279-335.

10. Halstenson CE, Macres M, Katz SA, Schnieders JR, Watanabe M, Sobota JT, et al. Comparative pharmacokinetics and pharmacodynamics of epoetinalfa and epoetin beta. Clin Pharmacol Ther 1991; 50(6):702-12.

11. Besarab A, Flaharty KK, Erslev AJ, McCrea JB, Vlasses PH, Medina $F$, et al. Clinical pharmacology and economics of recombinant human erythropoietin in end-stage renal disease: the case for subcutaneous administration. J Am Soc Nephrol 1992; 2(9):1405-16.

12. Weiss LG, Clyne N, Fihlho JD, Frisenette-Fich C, Kurkus J, Svensson B. The efficacy of once weekly compared with two or three times weekly subcutaneous epoetin $\beta$ : Results from a randomised controlled multicentre trial. Nephrol Dial Transplant 2000; 15(12):2014-9. doi: 10.1093/ndt/15. 12.2014.

13. Locatelli F, Baldamus CA, Villa G, Ganea A, de Francisco AL, Group S. Once-weekly compared with three-times-weekly subcutaneous epoetin $\beta$ : Results from a randomised, multicenter, therapeutic-equivalence study. Am J Kidney Dis 2002; 40(1):119-25. doi: 10.1053/ajkd.2002.33920.

14. Loughnan A, Ali GR, Abeygunasekara SC. Comparison of the therapeutic efficacy of epoetin beta and epoetinalfa in maintenance phase hemodialysis patients. Ren Fail 2011; 33(3):373-5. doi: 10.3109/0886022X.2011.559675.

15. Dhrolia MF, Nasir K, Imtiaz S, Ahmad A. Dialyzer reuse: Justified cost saving for south Asian region. J Coll Physicians Surg Pak 2014; 24(8):591-6.

16. Levin A, Stevens PE. Summary of KDIGO 2012 CKD Guideline: behind the scenes, need for guidance, and a framework for moving forward. Kidney Int 2014; 85(1): 49-61. doi: 10.1038/ki.2013.444.

17. Kalantar-Zadeh K, Lee GH, Miller JE, Streja E, Jing J, Robertson JA, et al. Predictors of hyporesponsiveness to erythropoiesis-stimulating agents in hemodialysis patients. Am J Kidney Dis 2009; 53(5):823-34. doi: 10.1053/j.ajkd. 2008.12.040.

18. Omrani HR, Golmohhamadi S, Hashemian AH, Vaysmoradi AZ, Safari-Faramani R. Therapeutic efficacy of erythropoietin alfa and erythropoietin beta in hemodialysis: A randomised controlled trial. J Ren Inj Prev 2018; 8(1):44-9.

19. Prasetya AA, Suprapti B, Shanti BD. Effectivity of erythropoietin alpha compared to erythropoietin beta in patients with chronic kidney disease-anemia on hemodialysis. Folia Medica Indonesiana 2019; 55(2):82-8. 